\title{
STUDIES ON THE COMPOSITION OF THE FIBRINOID MATERIAL OF THE SUBCUTANEOUS NODULE OF RHEUMATOID ARTHRITIS ${ }^{1}$
}

\author{
By MORRIS ZIFF, THOMAS KANTOR, EDWARD BIEN, ${ }^{2}$ AND ALFRED SMITH \\ (From the Study Group on Rheumatic Diseases and the Departments of Medicine and Pathology, \\ New York University College of Medicine, New York, N. Y.)
}

(Submitted for publication June 19, 1953; accepted August 18, 1953)

Fibrinoid has been described as a "homogeneous, eosinophilic, refractile, relatively acellular, bandlike structure which has some of the tinctorial properties of fibrin" $(1,2)$. It is found in the connective tissue in a number of diseases, especially in the group of "diffuse collagen diseases" (3-5), including rheumatic fever and rheumatoid arthritis $(6,7)$, lupus erythematosus and scleroderma (3, 8-10), and periarteritis nodosa (11). In these diseases, the presence of fibrinoid material in close association with the fibrillar structures of the connective tissue is perhaps, histologically, the single common denominator $(4,5)$. Altschuler and Angevine $(1,2)$ have listed numerous other sites of occurrence of fibrinoid which include the base of peptic ulcers (12), the normal placenta (13), and lesions associated with hyperergic inflammation (14). The production of fibrinoid by a variety of experimental stimuli has been described; these include pinching of tissue (15), orthostatic hypotension (16), prolonged passive hyperemia (17), and massive administration of desoxycorticosterone (18).

Our present knowledge about fibrinoid is derived almost exclusively from studies of its histological staining characteristics. The latter are in most instances similar to those of fibrin, hence the name fibrinoid; and it has indeed been suggested $(16,19)$ that fibrinoid consists of inspissated fibrin and other blood proteins. Since fibrinoid often seems to blend with ragged or split bundles of otherwise normal-appearing collagen, Bahrmann (20) concluded that fibrinoid resulted

\footnotetext{
1 This investigation was supported (in part) by a grant from the Masonic Foundation for Medical Research and Human Welfare, and (in part) by research grant No. HG 909 A\&R, from the National Heart Institute, of the National Institutes of Health, Public Health Service.

2 Present address: Department of Chemistry, Meadowbrook Hospital, Nassau County, Long Island, N. Y.
}

from infiltration of degenerated collagen fibers by fibrin.

Klemperer, Pollack, and Baehr $(3,5)$ have suggested that change in the ground substance of the connective tissue as well as in the collagen fibrils contributes to the formation of fibrinoid. Altschuler and Angevine, on the basis of histochemical studies, concluded that the ground substance is the only constant element in the formation of fibrinoid (1) and that the essential feature of the fibrinoid change is the precipitation of the acid mucopolysaccharide of the ground substance by an alkaline protein $(1,2)$. This suggestion was based upon the finding of a close spatial relationship between fibrinoid and metachromatic staining substances and upon the demonstration, histologically, of positive polysaccharide and arginine staining reactions.

The X-ray pattern of the fibrinoid material in rheumatoid nodules has been recently described as a diffuse ring, quite distinct from that of fibrin and collagen (21). In electron photomicrographs, fibrinoid appeared as an amorphous material. Normal collagen was demonstrated by X-ray pattern and electron microscopic appearance to be in close association with the fibrinoid.

Enzymatic digestion of the fibrinoid in nodules of rheumatic fever has been studied recently by Glynn and Loewi (22). From observations that the fibrinoid in this tissue was resistant to digestion by trypsin over a period of three hours, but was digested by a collagenase preparation from Clostridium Welchii, the authors concluded that fibrinoid is related in structure to collagen.

In order to study the relationship between collagen and fibrinoid, analytical studies of the fibrinoid material of the subcutaneous nodule of rheumatoid arthritis were undertaken. The amino acid, hydroxyproline, constitutes between 13 and 14 per cent of collagen derived from a variety of 
sources (23) and is found in no other protein of the body, except for the small amount present in elastin. Hydroxyproline provides, therefore, a useful means of identifying the presence of collagen in tissue.

The hydroxyproline content of the collagen of the subcutaneous nodule and synovial membrane of rheumatoid arthritis was shown by Bien and Ziff (24) to be the same as that found in purified collagen from a number of normal tissues. Furthermore, the total hydroxyproline content of nodules and of synovial membrane was accounted for completely by the collagen and elastin fractions. It was inferred from this that hydroxyproline was not present in significant amounts in the fibrinoid material of the tissue analyzed.

In the present investigation, previously reported in abstract form (25), fibrinoid has been extracted from rheumatoid nodules by treatment with either dilute alkali or trypsin. The completeness of extraction has been demonstrated by histological section of the extracted tissue. The extracts so obtained have been hydrolyzed and analyzed for hydroxyproline by a sensitive radioisotope chromatographic technique (26), which is described below. The amounts of hydroxyproline found in the extracted fibrinoid were negligible in quantity and of the same magnitude as obtained in extracts of normal skin under the same conditions.

\section{METHODS}

The following general procedure was employed; details are given below. Subcutaneous rheumatoid nodules were extracted by two methods which removed the fibrinoid material, and the hydroxyproline content of the fibrinoid-containing extracts was determined. The collagen concentration of the whole nodule tissue was determined by direct analysis. By comparing the relative areas of collagen and fibrinoid on projections of representative stained microscopic sections, the approximate concentration of fibrinoid per gram of wet tissue was calculated. From the hydroxyproline content of the fibrinoid extracts, and the concentration of fibrinoid in the untreated tissue, the maximum percentage of collagen in the fibrinoid was then calculated.

Nodules were obtained from patients with long-standing rheumatoid arthritis, all of them untreated, and with active disease at the time of excision. In one patient, nodules were removed before and after administration of corticotropin. The nodules had been present for periods ranging from one to three years, and all except one, nodule $S$, were situated below the olecranon process of the forearm. Nodule $S$ was removed from the sub- cutaneous tissue located over the anterior superior iliac spine. In one nodule which showed cystic changes (nodule $\mathrm{V}_{1}$ ), only the solid portions were used for analysis.

Extraction of nodule tissue: One-half to one gram of nodule tissue was minced in a cold chamber to particles about $3 \mathrm{~mm}$. in diameter, weighed, covered with 40 to 60 $\mathrm{ml}$. of either $0.1 \mathrm{~N}$ or $0.05 \mathrm{~N}$ sodium hydroxide; or trypsin solution (containing $0.1 \mathrm{mg}$. of crystalline trypsin ${ }^{8}$ per $\mathrm{ml}$. of $0.02 \mathrm{M}$ borate buffer in physiological saline at $\mathrm{pH}$ $7.75)$; or borate buffer alone of the same composition, and shaken gently in a water bath at $37^{\circ} \mathrm{C}$. for 24 hours at 100 oscillations per minute. An adjacent slice of tissue was taken, as described below, for determination of collagen, and another for histological section. Following extraction of the mince, the supernatant was removed by centrifugation and the residue was washed gently four times with small volumes of physiological saline. The washings were added to the original extract and the resulting solution was diluted to a volume of $100 \mathrm{ml}$. Total nitrogen was determined by the Kjeldahl method. The residues were then covered with 10 per cent formalin. The final $\mathrm{pH}$ of the formalin bath ranged between 6 and 7 .

Determination of hydroxyproline: Aliquots of the nodule extracts, containing approximately one milligram of nitrogen, were hydrolyzed with an equal volume of concentrated hydrochloric acid for three hours at $\mathbf{5 0}$ pounds. The hydrolysate was then brought to dryness in vacuo, and hydrochloric acid was removed by repeating the evaporation twice after the addition of water. The residue was taken up in one $\mathrm{ml}$. of water while warming on a water bath. An aliquot of this solution, containing approximately $150 \mathrm{mcg}$. of nitrogen in $0.1 \mathrm{ml}$, was taken for determination of hydroxyproline by the pipsyl chloride method of Keston, Udenfriend, and Levy (26).

Pipsylation was carried out with $25 \mathrm{mg}$. of pipsyl (p-iodophenyl sulfonyl) chloride, containing approximately a million counts per micromole of $I^{m}$, dissolved in $0.6 \mathrm{ml}$. of half-saturated sodium bicarbonate. A known amount of pipsylhydroxyproline labeled with $S^{*}$, and having an activity of approximately 10,000 counts per minute, was added. The pipsyl derivatives were extracted with ether and chromatographed on paper for 48 hours at room temperature in $n$-amyl alcohol saturated with $2 \mathrm{~N}$ ammonia. The band demonstrating $S^{*}$ radiation was eluted with dilute ammonia, extracted with ether after acidification and re-chromatographed for 12 hours at room temperature in tetrachlorethane saturated with $2 \mathrm{~N}$ hydrochloric acid. The resulting band, produced by spreading of the pipsylhydroxyproline, was cut into strips, and ratios of $S^{2}$ to $I^{m}$ radiation were determined, using 0.015 inch aluminum foil filter. It was not possible to establish constancy of the ratio of $\mathrm{S}^{\mathrm{w}}$ to $\mathrm{I}^{\mathrm{m}}$ in the analysis of nodules $V_{1}$ and $K$ because of the small number of iodine counts available in the hydroxyproline bands. The procedure employed, however, was demonstrated in numerous other analyses to achieve separation of pure iands of pipsylhydroxyproline as demonstrated by constancy of $S^{\text {w }}$ to $I^{181}$ ratios. The effect of possible contamination of the

${ }^{8}$ Worthington Laboratories, Lot 303. 
pipsylhydroxyproline band by other pipsyl compounds containing $I^{131}$ would be to render the values reported maximal ones.

In a recovery experiment in which $18.1 \mathrm{mcg}$. of hydroxyproline was added to five $\mathrm{ml}$. of a $0.1 \mathrm{~N}$ sodium hydroxide extract of nodule $V_{1}$, and then autoclaved in hydrochloric acid, and analyzed as described above, 17.6 mcg. of hydroxyproline was recovered.

To establish the stability of both bound and free hydroxyproline in alkali under the conditions described, samples of gelatin and 1-hydroxyproline were incubated in $0.1 \mathrm{~N}$ alkali for 24 hours at $37^{\circ} \mathrm{C}$. One hundred milligrams of Baker's gelatin was found to contain $9.9 \mathrm{mg}$. of hydroxyproline when hydrolyzed directly and analyzed by the method of Neuman and Logan (23). After incubation in $100 \mathrm{ml}$. of $0.1 \mathrm{~N}$ sodium hydroxide under the conditions described, the hydroxyproline content was unchanged. Similarly when $10.2 \mathrm{mcg}$. of 1-hydroxyproline was incubated under the same conditions, $10.1 \mathrm{mcg}$. was recovered.

Determination of collagen: The content of collagen was determined on samples weighing between 0.3 and $1.0 \mathrm{Gm}$. and taken immediately adjacent to the thin slices, described below, from which the microscopic sections for estimation of fibrinoid-collagen ratios were prepared. Collagen was determined by the method of Lowry, Gilligan, and Katersky (27) on the basis of the nitrogen content of the gelatin supernatant assuming 17.5 per cent nitrogen in collagen.

Histological studies: In nodules $\mathrm{S}, \mathrm{V}_{1}$ and $\mathrm{V}_{2}$, a thin slice about $3 \mathrm{~mm}$. in width was removed from the center of the tissue to be analyzed, and microscopic sections from the above were stained by the van Gieson method for estimation of the relative amounts of fibrinoid and collagen (fibrinoid-collagen ratios) by the following technique: Careful tracings were made of the fibrinoid and collagen areas on lantern slide projections of the stained sections. The tracings representing areas of fibrinoid and collagen were then cut out, and weighed on an analytical balance. The relative weights of the tracings of fibrinoid and collagen were taken as approximations of the relative amounts of these materials in the tissue analyzed. In nodules $\mathrm{K}$ and $\mathrm{W}$, insufficient tissue was available for preparation of control sections prior to extraction. It was necessary, therefore, in these nodules to assume the proportion of fibrinoid in two ways: (1) from the histological appearance of serial sections of the extracted tissue, where areas previously occupied by fibrinoid, before extraction, could be identified by the small amounts of this material remaining; and (2) from the gross appearance of serially cut sections of fresh nodule tissue, in which regions of fibrinoid material are identifiable as greyish yellow areas. In these nodules, approximately the same relative amounts of fibrinoid and collagen were present as in nodules $\mathrm{S}, \mathrm{V}_{1}$ and $\mathrm{V}_{2}$.

Following fixation in 10 per cent formalin, the tissue residues, extracted as described above, as well as the control sections were dehydrated and embedded in paraffin. They were then serially sectioned at 5 microns and stained at intervals with each of the following stains, to establish the completeness of extraction: hematoxylin and eosin, van Gieson, phosphotungstic acid-hematoxylin, trichrome, orcein-picroaniline blue, Millon, toluidine blue, and periodic acid-Schiff. On a number of occasions, the formalin fixing solutions were evaporated to dryness, the residue hydrolyzed and analyzed for hydroxyproline by the method of Neuman and Logan. No hydroxyproline was found.

RESULTS

\section{Extraction of fibrinoid}

When minced nodule tissue was extracted with dilute sodium hydroxide solution, examination of serial sections of the extracted residues disclosed that approximately 80 per cent of the fibrinoid material had been removed (Figure 1c), and when the mince was extracted with trypsin solution (Figure 1d) practically all of the fibrinoid had been removed. Extraction of fibrinoid was apparent from the appearance of free spaces devoid of all tissue in the areas previously occupied by fibrinoid material in the control sections (Figure 1a). In these newly formed spaces, strands of intact collagen fibers previously obscured could be seen. Treatment with borate buffer at $\mathrm{pH}$ 7.75 , extracted relatively small amounts of fibrinoid (Figure 1b).

\section{Analytical data}

The concentration of collagen in the nodules analyzed ranged between 70.8 and $159 \cdot \mathrm{mg}$. per gram of fresh tissue (Table I). Fibrinoid concentration, calculated as the product of collagen concentration and fibrinoid-collagen ratio, averaged $29 \mathrm{mg}$. per gram (range 17 to $40 \mathrm{mg}$. per gram). From the amounts of hydroxyproline found by analysis of both the sodium hydroxide and trypsin extracts, which varied in different nodules from zero to $0.3 \mathrm{mg}$. per gram of fresh tissue, the maximum amounts of collagenous material which could be present in the extracted fibrinoid have been calculated. The presence of 13.4 per cent hydroxyproline in collagen (23) has been assumed. The values obtained, averaging $0.67 \mathrm{mg}$. per gram of tissue (range 0 to $2.20 \mathrm{mg}$. per gram), appear in all but one instance to be negligible in comparison with the amounts of fibrinoid calculated to be present. The amounts of hydroxyproline found are, moreover, of the 


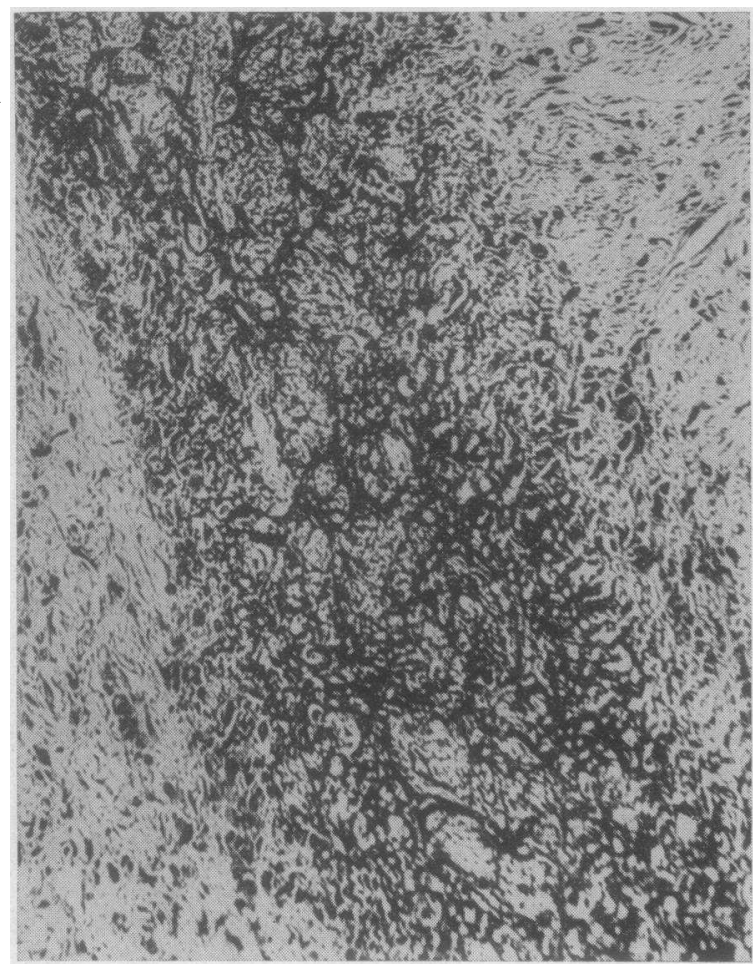

FIG. 1a

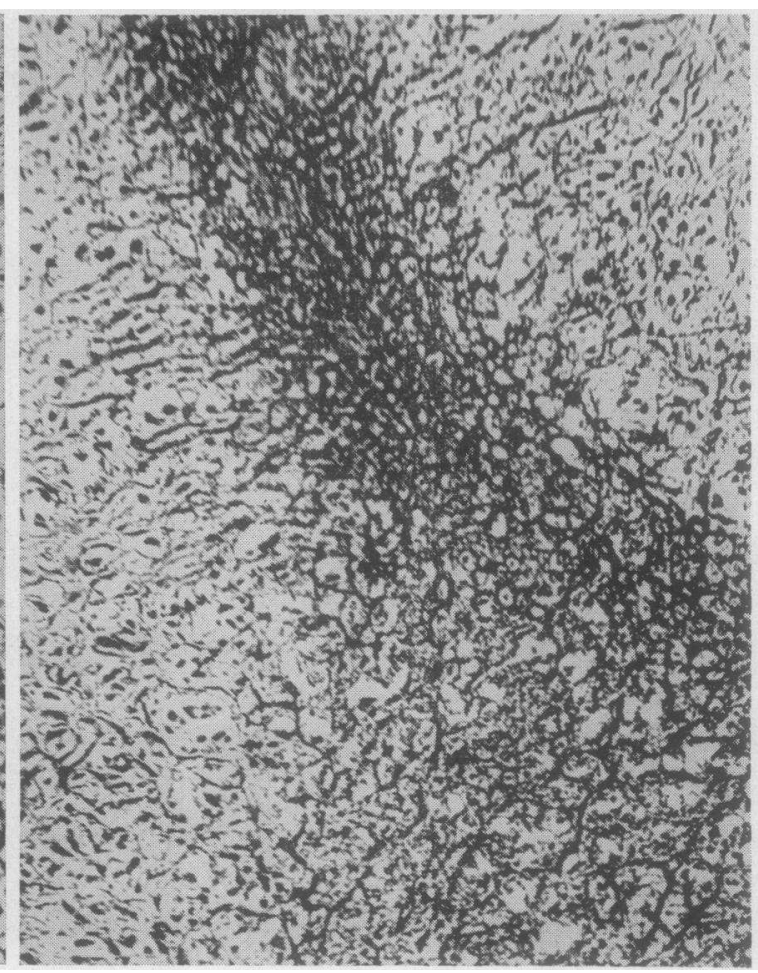

FIG. 1b

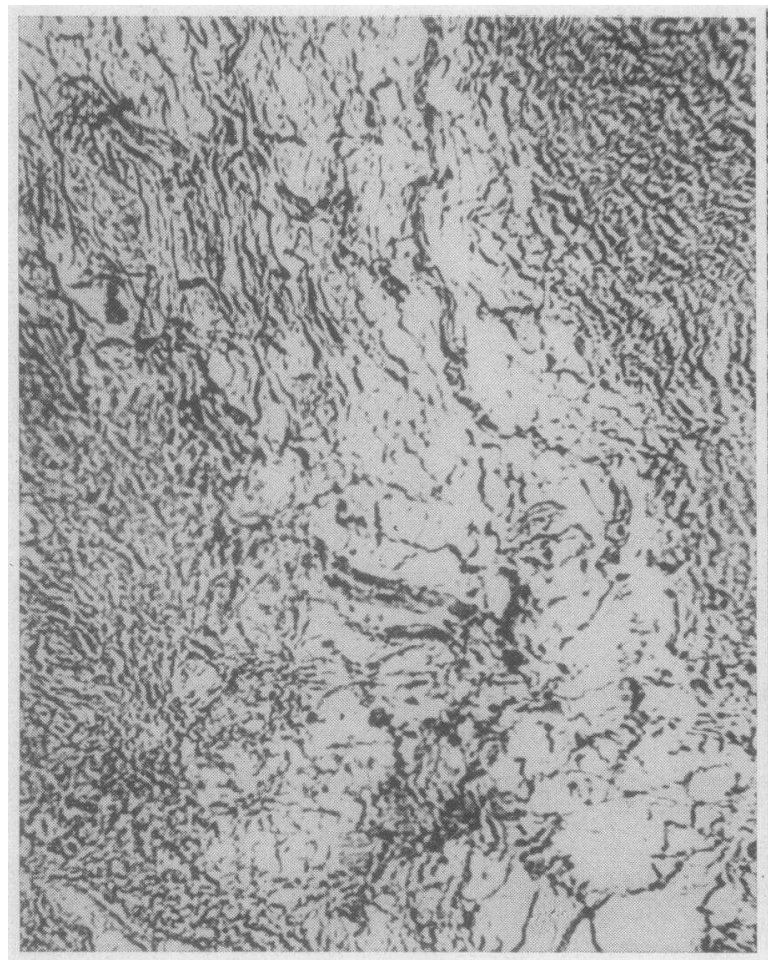

FIG. 1c

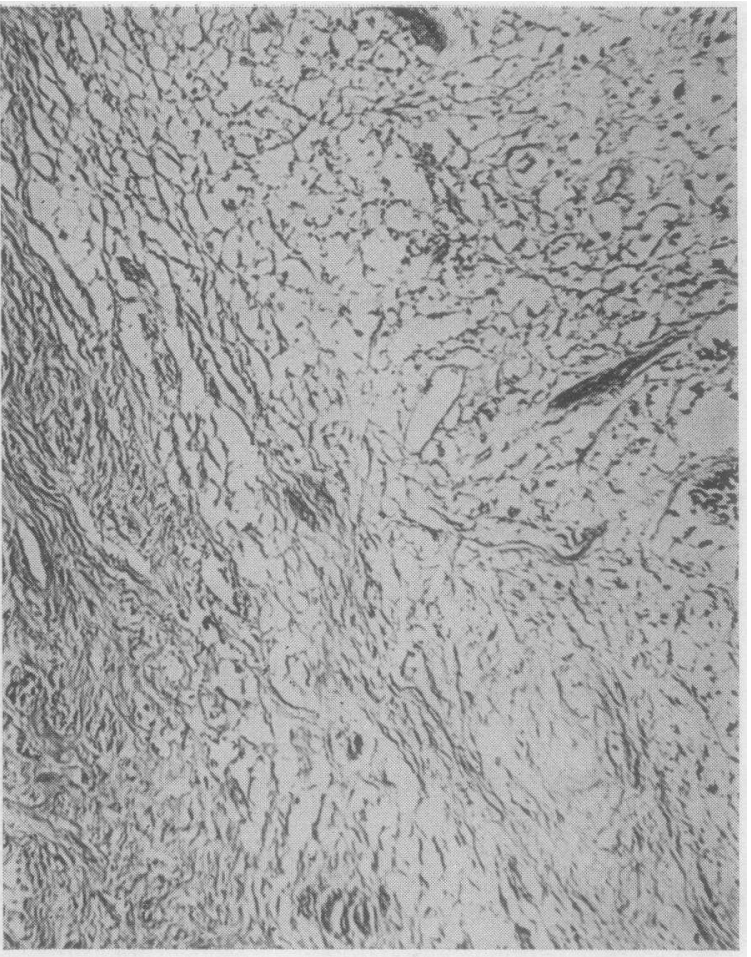

FIG. 1d 
TABLE I

Hydroxyproline content of extracts of subcutaneous nodules*

\begin{tabular}{|c|c|c|c|c|c|c|c|}
\hline Nodule & $\begin{array}{c}\text { Weight } \\
\text { sample } \\
\text { (Gm.) }\end{array}$ & $\begin{array}{l}\text { Collagen } \\
\text { found } \\
\text { (mg./Gm.) }\end{array}$ & $\begin{array}{l}\text { Fibrinoid- } \\
\text { collagen } \\
\text { ratio } \\
\text { measured }\end{array}$ & $\begin{array}{l}\text { Fibrinoid } \\
\text { calculated } \\
(\mathrm{mg} . / \mathrm{Gm} .)\end{array}$ & $\begin{array}{c}\text { Extraction } \\
\text { medium }\end{array}$ & $\begin{array}{c}\text { Hydroxy- } \\
\text { proline } \\
\text { extractable } \\
\text { foundt } \\
(\mathrm{mg} . / \mathrm{Gm} .)\end{array}$ & $\begin{array}{c}\text { Collagen } \\
\text { extractable } \\
\text { with fibrinoid } \\
\text { calculated } \\
(m g / / G m .)\end{array}$ \\
\hline $\mathbf{S}$ & 1.01 & 70.8 & 0.24 & 17 & $\begin{array}{l}\mathrm{NaOH} \\
0.1 \mathrm{~N}\end{array}$ & 0 & 0.00 \\
\hline$V_{1}$ & 1.16 & 104 & 0.26 & 27 & $\begin{array}{l}\mathrm{NaOH} \\
0.1 \mathrm{~N}\end{array}$ & 0.038 & 0.28 \\
\hline$V_{28}$ & 1.27 & 104 & 0.26 & 27 & Trypsin & 0.30 & 2.20 \\
\hline $\mathbf{K}$ & 0.676 & 135 & $0.25 \|$ & 34 & $\begin{array}{l}\mathrm{NaOH} \\
0.05 \mathrm{~N}\end{array}$ & 0.090 & 0.67 \\
\hline W & 0.283 & 159 & $0.25 \|$ & 40 & Trypsin & 0.025 & 0.19 \\
\hline
\end{tabular}

* All analyses are based on wet weight of tissue.

† When $0.627 \mathrm{Gm}$. of minced human skin was treated with $0.1 \mathrm{~N} \mathrm{NaOH}$ for 24 hours, 0.037 mg. hydroxyproline was extracted per gram of skin. When $0.674 \mathrm{Gm}$. of skin was similarly treated with a solution of $5 \mathrm{mg}$. of crystalline trypsin

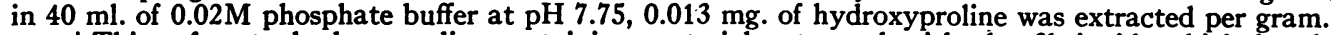

$\ddagger$ This refers to hydroxyproline-containing material extracted with the fibrinoid, which has been calculated as collagen, by multiplying hydroxyproline concentration by the factor 7.46 . nodule.

The patient (V) was treated with corticotropin for 16 days (total dose $3150 \mathrm{mg}$.) prior to excision of the second

II Values are approximate (see Methods).

same magnitude as found in normal human skin by treatment with dilute alkali or trypsin following the same procedure as applied to the nodules (Table I).

\section{DISCUSSION}

Fibrinoid is characteristically found in connective tissue in the "diseases of collagen". (8). Conclusions drawn from investigations of the fibrinoid material of subcutaneous nodules, however must of necessity be limited to this source, since there is no reason to assume that fibrinoid has the same composition in different diseases or even in different tissues. The rheumatoid nodule, moreover, when large enough to yield adequate amounts of tissue for chemical analysis, has usually been present for months to years. Since the composition of fibrinoid in nodules of long standing may differ from that of early nodules, conclusions drawn in the present report are limited by the age of the nodules analyzed, which was one to three years.

Our experiments indicate that the fibrinoid material of the subcutaneous nodule may be almost completely extracted by treatment with dilute alkali or trypsin. The extracts do not contain significant amounts of hydroxyproline. No hydroxyproline was extracted from nodule $\mathrm{S}$, and in three out of four other nodules from untreated patients, the largest concentration extractable was $0.09 \mathrm{mg}$. per gram of tissue. The small amounts of hydroxyproline extracted were approximately of the same magnitude as were obtained from normal skin by treatment with $0.1 \mathrm{~N}$ sodium hydroxide and trypsin. A relatively larger amount of hydroxyproline was removed from nodule $V_{2}$ on treatment with trypsin. This may perhaps be related to the fact that the patient had been treated with corticotropin for sixteen days prior to ex-

Fig. 1. Histological Sections of Subcutaneous Rheumatoid Nodules Illustrating Extraction of Fibrinoid (Nodule S, Trichrome Stain, Green Wratten B Filter, Magnified $120 \times$ )

a. Control section demonstrating areas of fibrinoid as dense black areas.

b. Section of residues following treatment with $0.02 \mathrm{M}$ borate buffer, in physiological saline, $\mathrm{pH} 7.75$, showing removal of small amounts of fibrinoid.

c. Residues following treatment with $0.1 \mathrm{~N}$ sodium hydroxide, demonstrating clear areas from which fibrinoid has been removed.

d. Residues following treatment with trypsin, in $0.02 \mathrm{M}$ borate buffer, $\mathrm{pH} 7.75$, demonstrating clear areas from which fibrinoid has been removed. 
cision of the nodule. A total dose of $3150 \mathrm{mg}$. of corticotropin had been administered.

On the basis of the amounts of hydroxyproline present in the fibrinoid extracts, it is calculated that an average of $0.67 \mathrm{mg}$. of collagen might have been extracted with approximately $30 \mathrm{mg}$. of fibrinoid. Collagen could constitute, therefore, about 2 per cent of the weight of fibrinoid. Since the hydroxyproline extracted probably represents the usual complement of this amino acid which is extractable from normal tissue, in view of the recovery of similar concentrations from normal skin, it is likely that little or no collagen is actually present in fibrinoid.

It should be pointed out that the values for the fibrinoid concentration of the unextracted tissue and the hydroxyproline content of the fibrinoid extract are given per gram of wet tissue. The results above, therefore, are independent of the amount of extraneous material extracted with the fibrinoid on treatment with alkali or trypsin. It should also be noted that, although the estimation of fibrinoid is necessarily approximate, appreciable error in this value would not change the overall conclusion because of the relatively small amounts of hydroxyproline recovered.

Though fibrinoid in minced tissue was digested by trypsin, it has been found to be resistant to hydrolysis by Clostridial collagenase (25). The stability of fibrinoid in collagenase solution is not surprising in view of the evidence that it does not contain appreciable amounts of hydroxyproline. Our observations with respect to enzyme digestion differ from those of Glynn and Loewi (22), who analyzed nodules from patients with rheumatic fever. These authors, however, incubated fixed tissue sections for three hour periods, whereas freshly minced tissue was digested for 24 hours in the present experiments.

There is no evidence that fibrinoid in the rheumatoid nodule, as histologically defined, is a homogenous substance. Studies of Kellgren and coworkers (21), using X-ray diffraction and the electron microscope, demonstrated patterns of an amorphous material in intimate contact with normal collagen fibrils. It is reasonable to assume that it is this amorphous material which has been extracted in the present experiments, leaving interspersing apparently normal collagen fibers behind (Figure 1). Our data suggest that degener- ated collagen is not present in the amorphous material of fibrinoid unless, of course, the collagen has been so altered in the process of degeneration that the hydroxyproline of the protein has been specifically lost or changed. The selective loss of individual amino acids in the degeneration of proteins finds little precedent, however.

The additional possibility remains, of course, that degeneration of collagen and subsequent removal of the degraded protein precedes the deposition of the fibrinoid material. If this were so, the first step in the fibrinoid change might very well be associated with an alteration of collagen, as suggested by the observations of Klinge (6). It would seem reasonable to assume from the data presented in this paper, however, that if altered collagen is formed, it is hydrolyzed by tissue proteases, and subsequently replaced by fibrinoid, the latter representing merely the end products of inflammation of connective tissue.

\section{SUM MARY}

The fibrinoid material of five subcutaneous nodules obtained from patients with rheumatoid arthritis has been extracted by treatment of fresh nodule tissue with either dilute sodium hydroxide or trypsin. The extracts of fibrinoid have been analyzed for hydroxyproline by a sensitive radioisotope derivative technique and found to contain between zero and $0.3 \mathrm{mg}$. of hydroxyproline per gram of nodule tissue.

Collagen content of the nodule tissue ranged between 70.8 and $159 \mathrm{mg}$. per gram. From the relative areas of collagen and fibrinoid present in microscopic sections of untreated nodules, the approximate concentration of fibrinoid has been estimated. Values varied between 17 and $40 \mathrm{mg}$. per gram.

The maximum amounts of collagen which could be present in the extracted fibrinoid, calculated from the hydroxyproline content of the fibrinoid extracts, were found to be about 2 per cent by weight of the fibrinoid. The results indicate that if collagenous material is at all present in the fibrinoid of the subcutaneous nodule, the amounts are negligible.

\section{ACKNOWLEDGMENTS}

The authors express their thanks to Drs. Albert Keston and Jean-Claud Dreyfus for their help in the isotopic analytical procedures. 


\section{REFERENCES}

1. Altschuler, C. H., and Angevine, D. M., Histochemical studies on the pathogenesis of fibrinoid. Am. J. Path., 1949, 25, 1061.

2. Altschuler, C. H., and Angevine, D. M., Acid mucopolysaccharide in degenerative disease of connective tissue, with special reference to serous inflammation. Am. J. Path., 1951, 27, 141.

3. Klemperer, P., Pollack, A. D., and Baehr, G., Diffuse collagen disease. Acute disseminated lupus erythematosus and diffuse scleroderma. J. A. M. A., 1942, 119, 331.

4. Klemperer, P., Diseases of the collagen system. Bull. New York Acad. Med., 1947, 23, 581.

5. Klemperer, $P$., The pathogenesis of lupus erythematosus and allied conditions. Ann. Int. Med., 1948, 28, 1.

6. Klinge, F., Der Rheumatismus; pathologisch-anatomische und experimentell-pathologische Tatsachen und ihre Auswertung für das ärztliche Rheumaproblem. Ergebn. d. allg. Path. u. path. Anat., 1933, 27, 1.

7. Bennett, G. A., Zeller, J. W., and Bauer, W., Subcutaneous nodules of rheumatoid arthritis and rheumatic fever; a pathologic study. Arch. Path., 1940, 30, 70.

8. Klemperer, P., Pollack, A. D., and Baehr, G., Pathology of disseminated lupus erythematosus. Arch. Path., 1941, 32, 569.

9. Masugi, M., and Yä-Shu, Die diffuse Sklerodermie und ihre Gefässveränderung. Virchows Arch. f. path. Anat., 1938, 302, 39.

10. Pollack, A. D., Visceral and vascular lesions in scleroderma. Arch. Path., 1940, 29, 859.

11. Gruber, G. B., Zur Frage der Periarteriitis nodosa, mit besonderer Berücksichtigung des Gallenblasenund Nieren-Beteiligung. Virchows Arch. f. path. Anat., 1925, 258, 441.

12. Askanazy, M., Utber Bau und Entsehung des chron. Magengeschwürs, sowie Soorpilzbefunde in ihm. Virchows Arch. f. path. Anat., 1921, 234, 111.

13. Grosser, O., Uber Fibrin und Fibrinoid in der Placenta. Ztschr. f. Anat. u. Entwicklungsgeschichte, 1925, 76, 304.
14. Gerlach, W., Studien ïber hyperergische Entzündung. Virchows Arch. f. path. Anat., 1923, 247, 294.

15. Wu, T. T., Uber Fibrinoidbildung der Haut nach unspezifischer Gewebsschädigung bei der Ratte. Virchows Arch. f. path. Anat., 1937, 300, 373.

16. Meessen, $H$., Uber Coronarinsuffizienz nach Histamincollaps und nach orthostatischem Collaps. Beitr. z. path. Anat. u. z. allg. Path., 1937, 99, 329.

17. Henschen, F., Uber eine eigenartige, mit Thrombenbildung verbundene Reaktion des Gefässendothels. Acta. med. Scandinav., 1926-27, 65, 539.

18. Selye, $H$., The general adaptation syndrome and the diseases of adaptation. J. Clin. Endocrinol., 1946, 6, 117.

19. Clark, E., Graef, I., and Chasis, H., Thrombosis of the aorta and coronary arteries. Arch. Path., 1936, 22, 183.

20. Bahrmann, E., Uber die fibrinoide Degeneration des Bindegewebes. Virchows Arch. f. path. Anat., 1937, 300, 342.

21. Kellgren, J. H., Ball, J., Astbury, W. T., Reed, R., and Beighton, E., Biophysical studies of rheumatoid connective tissue. Nature, 1951, 168, 493.

22. Glynn, L. E., and Loewi, G., Fibrinoid necrosis in rheumatic fever. J. Path. \& Bact., 1952, 64, 329.

23. Neuman, R. E., and Logan, M. A., The determination of hydroxyproline. J. Biol. Chem., 1950, 184, 299.

24. Bien, E. J., and Ziff, M., Fibrinoid and hydroxyproline of the rheumatoid subcutaneous nodule. Proc. Soc. Exper. Biol. \& Med., 1951, 78, 327.

25. Kantor, T., Sokoloff, L., Smith, A., and Ziff, M., Chemical and histological studies of the fibrinoid material of the subcutaneous rheumatoid nodule. Ann. Rheumat. Dis., 1951, 10, 471.

26. Keston, A. S., Udenfriend, S., and Levy, M., Determination of organic compounds as isotope derivatives. II. Amino acids by paper chromatographic and indicator techniques. J. Am. Chem. Soc., 1950, 72, 748 .

27. Lowry, O. H., Gilligan, D. R., and Katersky, E. M., The determination of collagen and elastin in tissues, with results obtained in various normal tissues from different species. J. Biol. Chem., 1941, 139, 795. 